This is a self-archived version of an original article. This version may differ from the original in pagination and typographic details.

Author(s): Okkonen, Ida; Takala, Tuomo

Title: Managers' Moral Struggle : A Case Study on Ethical Dilemmas and Ethical Decisionmaking in the Context of Immigration

Year: 2019

Version: Accepted version (Final draft)

Copyright: (c) 2019 Taylor \& Francis

Rights: In Copyright

Rights url: http://rightsstatements.org/page/InC/1.0/?language=en

Please cite the original version:

Okkonen, I., \& Takala, T. (2019). Managers' Moral Struggle : A Case Study on Ethical Dilemmas and Ethical Decision-making in the Context of Immigration. Ethics and Social Welfare, 13(4), 392-408. https://doi.org/10.1080/17496535.2019.1604784 


\section{Managers' Moral Struggle: A Case Study on Ethical Dilemmas and Ethical Decision- Making in the Context of Immigration}

Authors: Ida Okkonen, ida.a.m.okkonen@student.jyu.fi, +358500673334

(corresponding author)

Tuomo Takala, tuomo.a.takala.jyu.fi, +358503547566

Affiliations: University of Jyväskylä, School of Business and Economics

Address: $\quad$ P.O. Box 35, FI-40014 University of Jyväskylä, FINLAND

Figures: $\quad$ FIGURE 1 Types of ethical problems (Geva 2006).

FIGURE 2 Jones's (1991) issue-contingent model of ethical decision-making in organisations.

TABLE 1 Interviewees' level of education, work experience as a manager of a reception centre, and work experience in the immigration sector.

TABLE 2 Dimensions of moral intensity.

Keywords: ethical dilemmas, ethical decision-making, moral intensity, managers, immigration, reception centres 
Managers' Moral Struggle

\title{
Managers' Moral Struggle: A Case Study on Ethical Dilemmas and Ethical Decision- Making in the Context of Immigration
}

\begin{abstract}
This qualitative study explores the types of ethical dilemmas that Finnish managers working in reception centres for asylum seekers have encountered and whether the moral intensity of the ethical issues was observable in the ethical decision-making. It concludes that the majority of the managers interviewed encountered ethical dilemmas relating to the termination of reception services. The ethical dilemmas were stratified into seven groups: ambiguous or complete absence of relevant instructions, lack of support, conflicting values, withholding information, pressure, discretionary stress, and unjust decisions on asylum applications. In addition, various dimensions of moral intensity were observed in the managers' ethical decision-making, indicating that they recognised the ethical aspects of their moral dilemmas. Finally, theoretical and practical implications, as well as limitations and future propositions, are discussed.
\end{abstract}

\section{Introduction}

In recent decades, ethical dilemmas have been researched in both business/organisation and public administration contexts. However, research on ethical decision-making in organisations and research on discretion in street-level bureaucracy have developed quite independently (Loyens and Maesschalck 2010). Thus, decision-making research has focused mainly on various professionals in the business context (e.g. Dukerich et al. 2000; Dean et al. 2010; Figar and Dordević 2016), and research on the discretion of street-level bureaucrats has focused on police, teachers and social workers, for example (e.g. Lipsky 1980; Tymchuck 1982; Kelly 1994; Scott 1997; Banks and Williams 2005). There appears to be a research gap here, since ethical dilemmas and decision-making/discretion in the immigration context are far less studied (Dunkerley et al. 2005; Hagelund 2010; Eggebø 2012; Dörrenbächer 2017; Maylea and Hirsch 
Managers' Moral Struggle

2018), and none of the existing studies have specifically focused on the managers of reception centres.

Immigration encompasses a wide range of ethical considerations in addition to political and legal ones (Zapata-Barrero 2012; Bader 2012), and recently, many European countries have faced great challenges as the number of incoming asylum seekers has increased tremendously (UNHCR 2016). Hence, the aim of this paper is twofold. First, our purpose is to explore what kinds of ethical dilemmas managers have encountered in the context of immigration in Finland, and second, our aim is to investigate whether various dimensions of moral intensity are embedded in managers' ethical decision-making. Thus, this study poses the following research questions: 1) what kinds of ethical dilemmas do reception centre managers experience in their work, and 2) which dimensions of moral intensity are observable in the ethically challenging situations encountered by the managers? Applying our theoretical framework, we are interested in investigating how the current unsettled situation are perceived by managers and how the managerial profession is affected by the specific context. More specifically, our focus is on the termination of asylum seekers' reception services, which results in these individuals being left without social security and with minimal rights in Finnish society if they are unwilling to voluntarily return to their home countries or cannot forcibly be deported. A qualitative perspective was chosen for this research because it makes it possible to explain the meanings that real people give to the matters being investigated (Silverman 2014).

The study aims to contribute to organisational and managerial ethics research by revealing new scientific knowledge about reception centre managers' ethical dilemmas and their decision-making process and to shed light on the immigration issues encountered in this professional field. The study therefore seeks to make both a professional and a societal impact. The article is organised as follows. First, the empirical context is described, followed by a presentation of the theoretical framework of this research. Then, the methodology is described, 
Managers' Moral Struggle

after which we present the results. We go on to discuss the results in light of previous research, their possible implications, the limitations of the study, and future propositions.

\section{Empirical Context}

According to the Finnish Immigration Service, Finland received over 32000 asylum applications in 2015. Approximately 200 reception centres were established to give these asylum seekers access to basic services as they through the asylum process. In Finland, reception services are required by law (Act on the Reception of Persons Seeking International Protection, 746/2011) to include housing accommodations, food or kitchen facilities social and health care, reception allowance, legal aid, interpretation services, and employment and educational resources (Finnish Immigration Service 2016). The reception centres are operated by public or private organisations, the establishment of which is mandated by the Finnish Immigration Service.

Reception centres may be facility-based or residence-based. Most often asylum seekers are accommodated in facilities, but they may also be housed in private apartments arranged by an operating service provider. Some asylum seekers might choose to live with their relatives or friends, in which case they are not compensated for their accommodation. In the facilities, the number of employees is slightly higher than in residence-based accommodation. In a facility-based reception centre that provides services for 200 asylum seekers, there should be 14-15 employees, consisting of a manager, nurse(s), social advisor(s)/worker(s), instructors/advisors, and financial and administrative staff. (Finnish Immigration Service 2019).

The role of reception centre managers lies somewhere between managers in ordinary organisational contexts and street-level bureaucrats. Furthermore, these managers could be 
Managers' Moral Struggle

called middle managers since they have personnel below and above them. They have managerial responsibilities related to human resource, cost, service and stakeholder management, among others. Yet, they also have some responsibilities that are typical for streetlevel bureaucrats. For example, reception centre managers have the ability to exercise a certain amount of discretion and are able to prolong the time that clients receive services after being rejected for a residence permit (e.g. if one's health is at stake), but only to a certain extent. Managers working in reception centres are not, however, strictly street-level bureaucrats, as they are not employed directly by bureaucratic agencies. For instance, the managers of reception centres do not make decisions regarding asylum applications, but the asylum applications are processed by the Finnish Immigration Service.

\section{Theoretical Framework}

A number of studies have investigated ethical dilemmas in a business context (Likierman 1989; Dukerich et al. 2000; McNeil and Pedigo 2001; Leitsch 2006; Dean et al. 2010) and in a public administration context (Lipsky 1980; Kelly 1994; Kelley and Elm 2003; Dunkerley et al. 2005; Banks and Williams 2005; Hagelund 2010; Eggebø 2012; Dörrenbächer 2017; Maylea and Hirsch 2018). Researchers find that middle managers especially face pressure not only from organisation members but also from different stakeholders, and this often leads to situations where complex, novel, and ambiguous ethical problems must be solved (Dukerich et al. 2000; Lämsä and Takala 2000; McNeil and Pedigo 2001; Dean et al. 2010). It has also been suggested that middle managers are the most pressured organisational group in terms of morality (Treviño et al. 2008).

According to Lipsky (1980), street-level bureaucrats deliver benefits and sanctions that delimit and influence people's lives to a great degree, and as a result they aid in policy-making 
and realisation. Thus, they likely encounter ethical dilemmas that are inherent to their professional context. It is suggested that dilemmas occur, for example, when values and ideologies conflict with policy goals (e.g. Lipsky 1980). Consequently, in the welfare context, the nature of ethical dilemmas differs somewhat from that which is found in a traditional business context (e.g. Kelley and Elm 2003; Eggebø 2012). Eggebø (2012) further argues that in immigration administration, employees are challenged as ethical beings more than they are in any other bureaucratic organisation due to the greater amount of control and restriction, referring to depersonalised bureaucratic systems that are "independent of feelings and personal commitments and displace moral concerns and dilemmas" (303).

Geva (2006) suggests that different types of problems require different types of solutions. To improve ethical problem-solving and ethical conduct in organisational settings, moral issues should be recognisable and categorisable. Geva offers a model of types of ethical problems (Figure 1). The cross-classification of two ethical conduct dimensions - moral judgment and moral motivation - creates four types of ethical dilemmas: a genuine dilemma (two or more ethical requirements conflict); a compliance problem (it is clear what the right thing to do is, but the morally right thing to do is prohibited); moral laxity (a lack of concrete obligations); and a no problem-problem (where there is willingness as well as ability to pursue the moral goal). According to Geva (2006), the typology can be applied to "three main goals of ethics management in organizations: developing ethical awareness, assigning accountability, and unfolding typical rationalizations in business activity" (134).

Geva's typology is constructed in a business context and with a managerial perspective in mind. For example, Hiekkataipale and Lämsä (2016) apply Geva's (2006) typology in their study on middle managers' ethical problems in the context of higher education. However, we presume that the ethical dilemmas encountered by managers in the context of immigration could be categorised using the same typology. We further assume that managers encounter 
Managers' Moral Struggle

ethical dilemmas that are unique to the investigated context. Finally, we assume that managers working in reception centres experience demands from various stakeholders (e.g. the Finnish Immigration Service, other organisational members, and possibly from asylum seekers) as well as role ambiguities, which may result in distress.

FIGURE 1

Theoretical ethical decision-making models (e.g. Ferrell and Gresham 1985; Rest 1986; Treviño 1986; Jones 1991) and empirical research on ethical decision-making have often focused on the personal characteristics of the moral agent, like their professional roles, role conflict, job satisfaction (Yetmar and Eastman 2000; Bobek et al. 2015), ethical orientation (Rallapalli et al. 1998; Johari et al. 2017), locus of control (Treviño and Youngblood 1990; Cherry and Fraedrich 2000), ego strength (Treviño 1986), managerial leadership style (Fritzche and Becker 1984), moral intensity (Leitsch 2006; Kelley and Elm 2003; Valentine and Bateman 2011; Johari et al. 2017), and cognitive moral development (Kohlberg 1969; Herington and Weaven 2007), in addition to organisational factors like professional codes (Patterson 2001), organizational culture and climate (Forte 2004; Sweeney et al. 2010), and industry-specific norms and factors (Morris et al. 1995; Bobek et al. 2015).

Weber (1990) argues that prior research on ethical decision-making might be misleading or limited if the characteristics embodied in a moral issue are ignored, thus suggesting that moral reasoning is issue dependent. Jones (1991) especially criticises earlier models of ethical decision-making for not considering the characteristics of the moral issue itself and suggests 
Managers' Moral Struggle

that ethical evaluation and decision-making are affected by moral intensity that captures the heightened emotions and feelings in an ethical conflict situation.

Jones (1991) proposes an issue-contingent model (Figure 2) drawn from social psychology, where the moral intensity of an ethical issue serves as an independent variable influencing all four components in the decision-making process. Unlike most ethical decisionmaking theorists, Jones excludes organisational factors and the characteristics of the moral decision-maker from moral intensity and wants moral intensity to focus purely on the moral issue. The six dimensions of moral intensity are presented below.

\section{FIGURE 2}

Magnitude of consequences refers to the sum of the harms or benefits of the moral act being directed at its victims or beneficiaries, respectively. Social consensus is defined as "the degree of social agreement that a proposed act is evil (or good)" (Jones 1991, 375). Jones argues that social consensus reduces ambiguity in the face of ethical dilemmas, and so it facilitates both logical and ethical behaviour. Probability of effect refers to the probability of the moral act in question actually taking place and having consequences (harm or benefit) for the recipient. Temporal immediacy refers to the "length of time between the present and the onset of the consequences of the moral act in question" (Jones 1991, 376). Briefly, Jones proposes that a shorter length of time leads to greater immediacy whereas a greater length of time leads to discounting the magnitude of the consequences. Proximity (social, cultural, psychological and physical) is defined as the feeling of closeness that the moral agent has to the victims or beneficiaries in question. For example, in Milgram's (1974) experiment, the participants who felt close to the recipients were less likely to obey the authority's (harmful) commands (Jones 
Managers' Moral Struggle

1991, 377). Finally, concentration of effect, is defined as the inverse relationship between the number of people affected by an act and the magnitude of the consequences of the act. A sense of justice supposedly inhibits immoral behaviour that could result in highly concentrated effects.

Jones's theory faces criticism, for example, for not adequately accounting for decisionmaking's contextual factors. For instance, Kelley and Elm's (2003) qualitative study is based on the premise that context plays a central role in the decision-making process, and they study social workers' decision-making in relation to Jones's six dimensions of moral intensity. In line with previous research, they suggest that an appropriate assessment of the context performs an important role in decision-making (e.g. Treviño 1986; Messick and Bazerman 1996). Dean et al. (2010) also observe that levels of organisational structure, legal constraints, and professional codes all narrow down the possible decisions that could be made by preventing the use of moral reasoning and cause "psychic struggle" because an action might be organisationally acceptable but morally wrong. They conclude that the organisational context both limits and guides ethical decision-making.

In this study, we presume that the context is more important in managers' ethical decision-making than Jones's model suggests. We believe that the magnitude of the consequences (consequences may have a great impact on recipients' lives), concentration of effect (consequences may be concentrated on only one or a few people), temporal immediacy (quick decision-making), social consensus (legislation and collegial support), and proximity (e.g. physical and psychological closeness to/distance from the recipients) may be represented in the ethical decision-making of the managers of reception centres. We did not include probability of effect in this investigation because of the nature of the managers' decisionmaking power. Finally, we assume that Jones's issue-contingent model, which has mostly been 
Managers' Moral Struggle

developed for and applied in the private sector, is also applicable in the immigration context, which is in line with Kelley and Elm's (2003) study on public administration.

\section{Research Methods}

\section{Procedure}

Semi-structured interviews were chosen as our method because they follow the general interview guide approach (focused interview). Instead of asking fixed questions, the interview follows specific predetermined topics, thus giving the interviewer the freedom to build the conversation within the subject area and spontaneously rephrase the questions if necessary. This open-ended strategy implies that informants will be encouraged to elaborate on their accounts, and the inquiry is flexible and adapted to the particular research problem, the particular experiences of individual participants and their ability to communicate them. Thus, this method allows interviewees' perspectives and experiences to emerge, making each interview unique. (Patton 2002, 343-344; Elliott and Timulak 2005, 150).

To gather our participants, we called reception centres' offices and asked for their managers' contact information, i.e. their office phone numbers, since this information was not publicly available. Not all the numbers we requested were given, but we used the ones that we did receive to contact the managers. After briefly explaining the purpose of the study, we asked them if they would be willing to take part in this research.. A follow-up email was sent to the managers after the phone call, to again briefly describing the purpose of the study, its main concepts, and their rights as participants (this was reiterated before each interview). In the email, the participants were also asked to think about an ethically challenging situation they had encountered, so that they would be able to talk about it more easily in the interview. It was made clear to the managers that they had the right to discontinue their participation at any point 
Managers' Moral Struggle

during the research, and they were assured that their anonymity would be preserved. Some participants asked to be allowed to read the extracts from the interviews that would be used in the study, and we agreed to this request.

Ten interviews were conducted between January and March 2017. Most of them were done by phone because the reception centres were located in different parts of Finland, but two managers were interviewed face-to-face in their workplaces. The interviews were constructed using the following sequence of topics: (i) background information; (ii) general questions (e.g. did the manager have any doubts about applying for the job?); and (iii) an ethically demanding situation including; a) a description of the situation (e.g. what happened, who was involved?); b) its consequences (e.g. what were the consequences, how did the manager and others feel and react?); c) the solution (e.g. how was it resolved?); d) the reasons in cases where there was no solution; and e) the situation afterward (e.g. could the manager have acted differently, what were the consequences in the end?). Once we noticed that the interviewees' stories began to repeat a similar theme, we did not conduct any further interviews. The interviews were audiotaped and transcribed in Finnish and later translated into English.

In this study, the data were analysed by means of thematic analysis, which supported an understanding and recognition of certain emerging patterns in the seemingly random information. It allowed us to identify certain themes from recurring words and issues raised in the interviews. (Patton 2002, 452-453; Marshall and Rossman 2006, 158-159). In other words, we proceeded by first identifying particular themes from recurring words (ethical dilemmas) and then categorising the characteristics of the ethical dilemmas (following Geva's [2006] typology of moral problems). Finally, we examined the ethical dilemmas with respect to Jones's 1991 dimensions of moral intensity. The data were analysed by a team effort in the sense that the results were discussed by the first and second authors. In other words, the interpretation of the results was a joint effort. Finally, one of the interviews was excluded from 
Managers' Moral Struggle

the study after analysing it because the interviewee's dilemma was entirely concerned with the termination of an employment relationship. This exclusion allowed us to focus on a unique dilemma situation that emerged in this specific context, namely the termination of reception services.

\section{Interviewees}

In this study, 10 managers working in reception centres in Finland were interviewed (Table 1). The participants were randomly selected from a public list of reception centres in operation (79 centres) at the time of conducting this study. The data collection was based on purposeful sampling, meaning that the managers who were interviewed were chosen with this specific context in mind. However, the selection of managers was not based on any other criteria. The purposeful sampling strategy was chosen because the immigration crisis in Finland and managers working in this context offered a unique case and a unique sample for investigation. In addition, the selection was based on the anticipated richness and relevance of the information in light of the research questions posed by this study. (Patton 2002, 230, 240-241; Yin 2011, 311).

The managers' average age was 43.5 years, the oldest being 62 and the youngest 31 years old. All of the interviewees had some kind of management experience before taking up their current position, but they came from a variety of backgrounds (nursing, social, military and administrative sciences). At the time of the interviews, 210 asylum seekers (clients) and 20 employees were on average in each of the reception centres in which the interviewees worked.

\section{TABLE 1}


Managers' Moral Struggle

\section{Results of the Study}

In the following sections we present our results, in two parts: ethical dilemmas and dimensions of the moral intensity of ethical issues.

\section{Managers' Ethical Dilemmas}

We found that the managers encountered three types of ethical dilemmas according to Geva's (2006) typology of ethical dilemmas: genuine ethical dilemmas, compliance problems, and no problem-problems. Managers faced ethical dilemmas that they considered ambiguous or that demonstrated a lack of instructions and policies, lack of support, problems with conflicting values, withholding information, pressure, discretion, and unjust decisions on asylum applications. All the ethically challenging situations related to termination the of reception services.

\section{Genuine ethical dilemmas}

Genuine ethical dilemmas were the most frequently encountered by the managers interviewed. Genuine ethical dilemmas appeared when the managers were motivated to resolve the situation but faced difficulties in choosing the most ethically sound course of action. Unclear instructions or a lack of instructions resulted in distress, and an absence of support was closely related to a lack of instructions. In these situations, managers could not get the support they needed to make challenging decisions. Finally, distress was caused by uncertainty regarding how to act professionally but also morally right when the decision would have a significant impact on the 
Managers' Moral Struggle

client's life. An example of this is illustrated by one manager who felt uncertainty facing a situation in which the reception services had to be terminated. She noted:

It was a totally new thing... and then came the first ones, (...) no one had much experience and knowledge about it, and there wasn't that much information about it either. So of course, it affects [you], even though I had quite a lot of experience with everything. (...) So where could I have got the support from? [Alice]

Value conflicts occurred when personal values contradicted professional ones (e.g. current managerial position) or when professional values or ideologies (adopted professional ethics) conflicted with policies and policy goals (e.g. legislation). For instance, often managers felt that their current managerial position and the professionalism related to it contradicted personal values. Thus, they had to choose which course of action they would take: either follow their own personal values or obey the law and the instructions they were given. As one manager noted:

The instructions sometimes are such that you have to discuss with yourself before you know how to deal with them [termination of reception services]. (...). Sometimes I have to sell some ideas to myself and think rationally about them, then I kind of have to leave those personal feelings and thoughts behind. [Eva]

Withholding information referred to concealing information from clients, for example, because of professional confidentiality. It could also relate to an ethically challenging situation where an action inevitably harmed another party. For instance, one manager had to decide whether to 
Managers' Moral Struggle

inform the mother and child about their residence permit or wait for the father's decision. However, the manager believed that the father would not get a positive decision and as the mentally unstable and suicidal mother could not properly take care of the child, the child would be taken into custody and most likely be separated from the parents. The case was problematic both in terms of the child's custody and mother's suicidal intentions. The manager stated:

Mostly, I've had a personal inner struggle with myself concerning whether releasing to the mother her [positive] decision could have saved her from suicide. [James]

Pressure referred to subtle or strong pressure from various stakeholders to obey the instructions given, such as from higher-level management or state agents. This was evident in situations where managers refused to terminate the reception services. As one manager recounted:

I saw the risks and that kind of inhumanity quite strongly, (...). I wasn't willing to terminate the services until a government body actually contacted me and required more evidence regarding the justifications for continuing them. And at that point the organisation also began demanding the same thing. [David]

The manager's divergent behaviour posed a threat to the implementation and goals of the policy. Thus, his deviant behaviour was considered undesirable and led to him facing pressure from different parties, like state agents. Managers experienced discretionary stress when they acknowledged the magnitude of their responsibility to make the right decisions on the termination of reception services being great, but there was a lot of uncertainty as well. 
Managers' Moral Struggle

Discretion was closely related to exposition of the clients. The managers were afraid that they could be accused of abandoning clients and possibly violating their human rights. For example, one manager pondered:

I believe that the most difficult cases will be the ones where you must consider the client's health status - could it get worse? Or if there is a family with children to consider. (...) I wonder myself whether I could be accused of negligence if I terminated the services. Like, where would you draw the line? [Eva]

Finally, unjust decisions were closely related to the termination of reception services since their execution after an unfair asylum process created a genuine ethical dilemma for the managers. Often managers felt that asylum seekers were treated unfairly due to Finland's strict immigration policies. One manager confessed:

And I had to give up on the principle of justice because I knew... or that in my opinion, the asylum process hadn't gone right, and that's why the Supreme Administrative Court's decision, which was still pending, should have been waited for while [the client was] still in the reception centre, not homeless. [David]

\section{Compliance problems}

Compliance problems, where motivation was low but the dilemmas were clear, were encountered in value conflict situations especially - in other words, when policies and instructions conflicted with the managers' own values, ethical principles, and/or professional ethics. Often managers were obliged to obey the instructions given despite their own moral 
Managers' Moral Struggle

objections when calls for professionalism went against their personal values and caused inner moral conflict. One manager articulated as follows:

I brought up that this goes against my professional ethics and my worldview. Nevertheless, I have to execute the alignments and terminate the services (...), although I see that they [asylum seekers] don't have a reasonable chance to take care of their own basic health problems. [David]

Thus, policy goals often contradicted with street-level bureaucrats' own standards of professionalism and ideologies when the reception services had to be terminated.

Furthermore, compliance problems were present in situations where policies were ambiguous and sometimes conflicted with each other. An example of this is presented by a manager who stated:

There are these regulations on negligence. So, if you throw a person out of here, and they don't have a place to stay and it's -30 Celsius outside, you will certainly be guilty according to another law. [Peter]

The managers of then brought up the difficulty of using discretionary power in situations where they had to decide whether to continue or terminate the services. Finally, compliance problems were also encountered when managers considered the decisions made on asylum applications unjust. These situations referred to the managers' experienced injustice when the immigration policy forced asylum seekers to choose between returning to their home countries or homelessness after being declined a residence permit. 
Managers' Moral Struggle

No problem-problems

Ethical dilemmas that were defined as no problem-problems arose when managers felt that the instructions they had been given were ambiguous or they had received no instructions at all. However, in these cases managers knew what should be done and were highly motivated to act accordingly, for example, by trying to influence policy-making within their organisation. An example of this was offered by a manager who noted:

The government's proposal outlines certain kinds of situations when reception services could be continued for a period of time. And my organisation also has guidelines about continuing the services, but they aren't very specific either (...) so they haven't got a definite policy. [Amanda]

\section{Dimensions of Moral Intensity}

The managers' ethical dilemmas seemed to include different dimensions of moral intensity (Table 2). The magnitude of the consequences for asylum seekers was observable when managers realised that the consequences of their decisions would have a great impact on their client's life in the future. For example, managers found it was extremely difficult to make the decision to terminate reception services for a client with health issues because without a residence permit the client would not be able to get the proper treatment for their illness. In such cases, managers saw terminating services as cruel since it would greatly reduce their client's quality of life.

In this context, social consensus can be understood as acting according to socially acceptable guidelines, such as laws and government instructions, or as acting in agreement with 
Managers' Moral Struggle

a working community's or colleagues' support. It has been proposed that social consensus reduces the doubt that is prevalent in ethical dilemmas and facilitates logical, ethical and appropriate behaviour (Jones 1991). However, often the managers did not see any other way to act than according to the legislation (i.e. following the social consensus) despite their personal ethical values. Thus, the managers seemed to question the morality of the instructions and the legislation, perceiving the immigration law and asylum seeking-process as somewhat inhumane.

The temporal immediacy dimension seemed to be present in the managers' dilemma situations, as in the law there are certain time limits within which decisions must be made and certain operations carried out. In addition, proximity was represented as managers had usually known these clients for months and often met with them daily. Since the managers felt close to their clients, it was more difficult for them to carry out harmful acts based on the law. Managers often tried to cope with ethically demanding situations by excluding certain personal values and ethical judgments from their decision-making. This could be considered a sign of selfprotection. According to Lipsky (1980), some street-level bureaucrats quit their jobs or burn out relatively easily if they do not develop coping mechanisms and adjust "their attitudes to reflect lower expectations for themselves... and the potential of public policy" (xii), for example.

All of the managers we interviewed went beyond the call of duty and, in cooperation with municipalities, helped clients after they were no longer eligible for reception services. According to Jones (1991), helping behaviour is influenced by proximity since the more the moral actor knows about the situation, the closer the moral actor feels to the recipient. Finally, concentration of effect could be found in all the interviewees' stories since they considered that the harm caused to the individual asylum seeker by terminating reception services was great. 


\section{TABLE 2}

\section{Discussion and Conclusions}

The aim of this study was to examine what kind of dilemmas managers working in reception centres for immigrants in Finland encounter, and whether various dimensions of moral intensity were observable in the managers' ethical dilemma situations. In the following sections we will discuss the results with respect to ethical dilemmas and the moral intensity of moral issues. Then we will discuss the theoretical and practical implications of our study, our study's limitations, and put forward our suggestions for future research.

\section{Discussion of Research Findings}

In this study, the ethical dilemmas faced by managers concerned the termination of reception services for asylum seekers after their residence permit applications had already been rejected. Without residence permits, asylum seekers were forced to choose between a supported, voluntary return to their home country, forced deportation or staying illegally in Finland. The dilemmas could be divided into seven groups: ambiguous or complete absence of relevant instructions, lack of support, conflicting values, withholding information, pressure, discretionary stress, and unjust decisions on asylum applications.

We can conclude that the nature of the dilemmas encountered by the (middle) managers in this context differed from those usually encountered in the business context (e.g. Likierman 1989; Dukerich et al. 2000; McNeil and Pedigo 2001; Leitsch 2006; Dean et al. 2010). However, the ethical dilemmas face by the managers in this study shared certain similarities with those found in the contexts of social welfare and immigration administration (e.g. Kelley 
Managers' Moral Struggle

and Elm 2003; Dunkerley et al. 2005; Banks and Williams 2005; Eggebø 2012, Maylea and Hirsch 2018). Even though reception centres are not exactly bureaucratic organisations, they operate under the scope of immigration law and other government institutions, and are therefore subject to bureaucratic rules and formal justice to a certain extent.

Scholars proposed that managers especially face pressure from both organisation members and different stakeholders, which often leads to situations where complex, novel, and ambiguous ethical problems must be solved (Dukerich et al. 2000; Lämsä and Takala 2000; McNeil and Pedigo 2001; Dean et al. 2010), and our study supports this proposition. The interviewed managers seemed to face pressure from state agents and from their superiors, for instance. We can further conclude that the dilemmas encountered were clearly profession specific and affected by the context in which they emerged.

Jones's (1991) issue-contingent model assumes that the moral actor must notice the moral aspects of issues in order to make ethical decisions. Our results showed that various dimensions were represented in different combinations in the managers' ethical dilemma situations, and thus the managers recognised the ethical aspects of the moral issues they faced. For instance, the managers acknowledged that the decisions made concerning asylum applications were more or less a matter of life and death for the asylum seekers, which is in line with Kelley and Elm's (2003) study on social workers and their interactions with their clients. Although the managers in our study often felt guilty about and were afraid of ignoring and violating their clients' human rights, they usually lacked adequate decision-making/discretionary power in their dilemma situations due to the highly regulated nature of the context in which they work.

It is proposed that organisational factors have an effect on ethical decision-making (e.g. Treviño 1986; Messick and Bazerman 1996; May and Pauli 2002; Kelley and Elm 2003; Dean et al. 2010). For instance Dean et al. (2010) concluded that organisational members might experience a 'psychic struggle', when an action might be organisationally acceptable but 
Managers' Moral Struggle

morally wrong. The managers in our study experienced this kind of struggle because the instructions they were given were generally accepted (immigration law) but felt morally wrong and inhumane. This is also in line with Lipsky's (1980) arguments that street-level bureaucrats often experience a gap between their own ideals and personal values and those of the agencies they serve and the government's policies. Thus, we can conclude that context in this study plays an important role in ethical decision-making.

Lipsky (1980) also states that the street-level bureaucrats who do not quit their jobs, successfully develop coping strategies to close this gap. The managers in this study cooperated with the municipalities to ensure that unsuccessful asylum seekers who stayed on in Finland illegally received some basic services after the reception services were terminated. Managers decided to engage in this kind of helping behaviour even though it was not required or supported by policy-makers. This could be considered a coping strategy to alleviate the weight of their own moral struggle, as they often felt like powerless mediators.

\section{Theoretical Implications}

In this study, Geva's (2006) typology of ethical dilemmas helped us to determine whether the dilemmas faced by the managers were ethical in nature, which then led us to examine more closely the various dimensions of the moral intensity of the moral issues included in Jones's (1991) issue-contingent model. The results of the study support Jones's argument that it is important to recognise the moral aspects within the issues in ethical decision-making. However, it seems to us that context may play a more important role in ethical decision-making than is suggested in Jones' model, which is in line with previous research (e.g. Treviño 1986; Messick and Bazerman 1996; May and Pauli 2002; Kelley and Elm 2003; Dean et al. 2010). 
Managers' Moral Struggle

\section{Practical Implications}

This study has certain practical implications. When we look at the work done every day on the grass-roots level in Finnish reception centres we see that managers are put in a rather morally demanding position: the unexpected increase in the number of asylum seekers led to the need for changes in legislation and procedures, resulting in ambiguities and a lack of clarity in the instructions they have to follow. On the other hand, value conflicts are considered inescapable in certain professions (Lipsky 1980).

We would like to stress that the ethical issues, at least those related to the termination of services, are linked to broader political decisions, policies and legislation; therefore personal ethical doubts might always arise - even with clear instructions or collegial support. In this case, given the profession that is involved, the challenge seems to be a matter of fundamental types of dilemmas embedded in street-level bureaucracy and discretion in general. Thus, we hope that the results of this study will make the ethical aspects of managers' work in the immigration sector visible and increase the amount of attention paid to them in socio-political platforms.

\section{Limitations and Proposals for Future Research}

The number of interviewees was rather low to start with but dropped even lower after we decided to exclude one interview from the analysis. Consequently, the results of this case study can by no means be generalised and their interpretation is limited. Rather, the results should be treated as specific cases. In the future, a quantitative investigation of the topic would be a fruitful addition to the qualitative approach we have used in this study. 
Managers' Moral Struggle

It should be remembered that in qualitative studies the role of the investigator is critical, especially when the results are reported and analysed. That said, there is always room for interpretation and subjective understanding. In addition, the interviews were conducted in Finnish and then translated into English, which might have affected the tone of the transcripts to some extent. We are also aware that this study's data might have been biased due to the social desirability effect, as some of the managers expressed their concerns pertaining their obligation to maintain professional confidentiality. Since the matter we examined was sensitive in nature, there might have been some kind of moderation of the ethical dilemmas. The results and conclusions should therefore be considered indicative rather than the absolute truth. In any case, the results reveal some intriguing information about the ethical challenges that managers working in this specific sector encounter.

\section{Disclosure Statement}

No potential conflict of interest was reported by the authors.

\section{References}

Bader, V. 2012. "Moral, Ethical, and Realist Dilemmas of Transnational Governance of Migration." American Behavioral Scientist 56 (9): 1165-1182. doi: 10.1177/0002764212443819

Banks, S., and R, Williams. 2005. "Accounting for Ethical Difficulties in Social Welfare Work: Issues, Problems and Dilemmas." British Journal of Social Work 35: 1005-1022. doi: 10.1093/bjsw/bch199

Bobek, D. D., A. M. Hageman, and R. R. Radtke 2015. "The Effects of Professional Role, Decision Context, and Gender on the Ethical Decision Making of Public Accounting Professionals.” Behavioral Research in Accounting 27 (1): 55-78. doi: 10.2308/bria-51090 


\section{Managers' Moral Struggle}

Cherry, J., and J. Fraedrich. 2000. “An Empirical Investigation of Locus of Control and the Structure of Moral Reasoning: Examining the Ethical Decision-Making Processes of Sales Managers. Journal of Personal Selling and Sales Management 20 (3): 173-188. doi: $10.1080 / 08853134.2000 .10754237$

Dean, K. L., J. M. Beggs, and T. P. Keane. 2010. "Mid-Level Managers, Organizational Context, and (Un)ethical Encounters." Journal of Business Ethics 97: 51-69. doi: 10.1007/s10551-010-04950

Dukerich, J. M., M. J. Waller, E. George, and G. P. Huber. 2000. "Moral Intensity and Managerial Problem Solving. Journal of Business Ethics 24: 29-38. doi: 10.1023/A:1006030109047

Dunkerley, D., J. Scourfield, T. Maegusuku-Hewett, and N. Smalley. 2005. "The Experiences of Frontline Staff with Children Seeking Asylum. Social Policy \& Administration 39 (6): 640-652. doi: 10.1111/j.1467-9515.2005.00461.x

Dörrenbächer, N. 2017. "Europe at the Frontline: Analyzing Street-Level Motivations for the use of European Union Migration Law.” Journal of European Public Policy 24 (9): 1328-1347. doi: $10.1080 / 13501763.2017 .1314535$

Eggebø, H. 2012. "With a Heavy Heart: Ethics, Emotions and Rationality in Norwegian Immigration Administration.” Sociology 47 (2): 301-317. doi: 10.1177/0038038512437895

Elliott, R., and R. Timulak. 2005. Descriptive and Interpretative Approaches to Qualitative Research. In: Miles, J., and P. Gilbert. 2005. A Handbook of Research Methods for Clinical and Health Psychology. New York: Oxford University Press

Ferrell, O. C., and L. G. A. Gresham. 1985. “A Contingency Framework for Understanding Ethical Decision Making in Marketing.” Journal of Marketing 49 (3): 87-96. doi: 10.2307/1251618

Figar, N., and B. Dordević. 2016. “Managing an Ethical Dilemma.” Economic Themes 54 (3): 345-362. doi: 10.1515/ethemes-2016-0017

Finnish Immigration Services. 2016. “Key Figures on Immigration 2015. European Migration Network \& Finnish Immigration Services.” Accessed January 22018 <www.migri.fi>

Finnish Immigration Services. 2019. "Liite1: Vastaanottokeskusten henkilöstömitoitus” / “Appendix 1: Reception Centres’ Personnel Sizing”. Accessed January $222019<$ https://urly.fi/18vi> 


\section{Managers' Moral Struggle}

Forte, A. 2004. "Business Ethics: A Study of the Moral Reasoning of Selected Business Managers and the Influence of Organizational Ethical Climate.” Journal of Business Ethics 51: 167-173. doi: 10.1023/B:BUSI.0000033610.35181.ef

Fritzche, D. J., and H. Becker. 1984. "Linking Management Behavior to Ethical Philosophy - An Empirical Examination.” Academy of Management Journal 37 (1): 166-175. doi: $10.5465 / 255964$

Geva, A. 2006. "A Typology of Moral Problem in Business: A Framework for Ethical Management.” Journal of Business Ethics 69: 133-147. doi: 10.1007/s10551-006-9072-y

Hagelund, A. 2010. "Dealing with the Dilemmas: Integration at the Street-level in Norway." International Migration 48 (2): 79-102. doi:10.1111/j.1468-2435.2008.00497.x

Herington, C., and S. Weaven. 2008. "Improving Consistency for DIT Results Using Cluster Analysis." Journal of Business Ethics 80: 499-514. doi: 10.1007/s10551-007-9451-z

Hiekkataipale, M.-M., and Lämsä, A. -M. 2016. The ethical problems of middle managers and their perceived organizational consequences. Transformations in Business \& Economics 15 (3): 3652.

Johari, R. J., Z. Mohd-Sanusi, and V. K. Chong. 2017. 'Effects of Auditors' Ethical Orientation and Self-Interested Independence Threat on the Mediating Role of Moral Intensity and Ethical Decision-Making Process.” International Journal of Auditing 21: 38-58. doi: 10.1111/ijau. 12080

Jones, T. M. 1991. "Ethical Decision Making by Individuals in Organizations: An Issue-contingent Model." Academy of Management Review 16 (2): 366-395. doi: 10.5465/amr.1991.4278958

Kelley, P. C., and D. R. Elm 2003. “The Effect of Context on Moral Intensity of Ethical Issues: Revising Jones' Issue-Contingent Model." Journal of Business Ethics 48: 139-154. doi: 10.1023/B:BUSI.0000004594.61954.73

Kelly, M. 1994. "Theories of Justice and Street-Level Bureaucracy." Journal of Public Administration Research and Theory 4 (2): 119-140.

Kohlberg, L. 1969. "Stage and Sequence: The Cognitive-Developmental Approach to Socialization." In: Goslin, D. A. 1969. Handbook of Socialization Theory. Chicago: Rand McNally

Leitsch, D. L. 2006. “Using Dimensions of Moral Intensity to Predict Ethical Decision-Making in 
Managers' Moral Struggle

Accounting." Accounting Education. An International Journal 15 (2): 135-149. doi: $10.1080 / 06939280600609151$

Likierman, A. 1989. "Ethical Dilemmas for Accountants: A United Kingdom Perspective." Journal of Business Ethics 8: 617-629. doi: 10.1007/BF00383030

Lipsky, M. 1980. Street-Level Bureaucracy - Dilemmas of the Individual in Public Services. New York: Russel Sage Foundation

Loyens, K., and J. Maesschalck. 2010. "Toward a Theoretical Framework for Ethical Decision Making of Street-level Bureaucracy". Administration \& Society 42:66-100. doi: $10.1177 / 0095399710362524$

Lämsä, A-M., and T. Takala. 2000. "Downsizing and Ethics of Personnel Dismissals - The Case of Finnish Managers". Journal of Business Ethics 23: 389-399. doi: 10.1023/A:1006134617764

Marshall, C., and G. B. Rossman. 2006. Designing Qualitative Research. $4^{\text {th }}$ ed. CA: Thousand Oaks, Sage Publications

May, D. R., and K. P. Pauli. 2002. "The Role of Moral Intensity in Ethical Decision Making: Review and Investigation of Moral Recognition Evaluation and Intention. Business and Society 4 (1): 84117. doi: $10.1177 / 0007650302041001006$

Maylea, C., and A. Hirsch. 2018. "Social Workers as Collaborators? The Ethics of Working within Australia's Asylum System." Ethics and Social Welfare 12 (2): 160-178. doi: $10.1080 / 17496535.2017 .1310918$

McNeil, M., and K. Pedigo. 2001. "Western Australian Managers Tell Their Stories: Ethical Challenges in International Business Operations." Journal of Business Ethics 30 (4): 305-317. doi: 10.1023/A:1010762619866

Messick, D. M., and M. H. Bazerman. 1996. "Ethical Leadership and Psychology of Decision Making. Sloan Management Review 37 (2): 9-22.

Morris, S. A., K. A. Rehbein, J. C. Hosseini, and R. L. Armacost. 1995. "A Test of Environmental, Situational and Personal Influences on the Ethical Intentions of CEO's.” Business and Society 34 (2): 119-147. doi: 10.1177/000765039503400202

Patterson, D. M. 2001. “Causal Effects of Regulatory, Organizational and Personal Factors and Ethical 
Managers' Moral Struggle

Sensitivity.” Journal of Business Ethics 30 (2): 123-159. doi: 10.1023/A:1006350614527

Patton, M. Q. 2002. Qualitative Research \& Evaluation Methods. $3^{\text {rd }}$ ed. CA: Thousand Oaks, Sage Publications

Rest, J. R. 1986. Moral Development: Advances in Research and Theory. New York: Praeger. In: Treviño, L. K., G. R. Weaver, and S. J. Reynolds. 2006. "Behavioral Ethics in Organizations: A Review." Journal of Management 32 (6): 951-990.

Rallapalli, K. C., S. J. Vitell, and J. H. Barnes. 1998. “The Influence of Norms on Ethical Judgments and Intentions: An Empirical Study of Marketing Professionals." Journal of Business Research 43: 157-168. doi: 10.1016/S0148-2963(97)00221-X

Scott, P. G. 1997. “Assessing Determinants of Bureaucratic Discretion: An experiment in Street-Level Decision Making." Journal of Public Administration Research and Theory 7 (1): 35-57. doi: 10.1093/oxfordjournals.jpart.a024341

Silverman, D. 2014. Interpreting Qualitative Data. London: Sage Publications

Sweeney, B., D. Arnold, and B. Pierce. 2010. "The Impact of Perceived Ethical Culture of the Firm and Demographic Variables on Auditors' Ethical Evaluation and Intention to Act Decisions. Journal of Business Ethics 93: 531-551. doi: 10.1007/s10551-009-0237-3

Treviño, L. K. 1986. "Ethical Decision Making in Organizations: A Person-Situation interactionist model." Academy of Management Review 11 (3): 601-617.

Treviño, L. K., and S. A. Youngblood. 1990. "Bad Apples in Bad Barrels: A Causal Analysis of Ethical Decision Making Behavior.” Journal of Applied Psychology 75 (4): 447-476.

Treviño, L. K., Weaver, G. R., and Brown, M. E. 2008. It Is Lovely at the Top: Hierarchical Levels, Identities and Perceptions of Organizational Ethics. Business Ethics Quaterly 18(2): 233-252. doi: $10.1017 / \mathrm{S} 1052150 \mathrm{X} 00010952$

Tymchuck, A. J. 1982. "Strategies for Resolving Value Dilemmas." The American Behavioral Scientist 26 (2): 159-175.

UNHCR. 2016. "Global trends - Forced displacement in 2015." 2016 United nations High Commissioners for Refugees, 1-65. The UN Refugee Agency’s website. Accessed May 292017 $<$ www.unhcr.org $>$

Valentine, S. R., and C. R. Bateman. 2011. "The Impact of Ethical Ideologies, Moral Intensity, and 
Managers' Moral Struggle

Social Context on Sales-Based Ethical Reasoning.” Journal of Business Ethics 102: 155-168. doi: 10.1007/s10551-011-0807-z

Weber, J. 1990. "Managers' Moral Reasoning: Assessing Their Responses to Three Moral Dilemmas." Human Relations 43: 687-702. doi: 10.1177/001872679004300705

Yetmar, S. A., and K. K. Eastman. 2000. “Tax Practitioners' Ethical Sensitivity: A Model and Empirical Examination.” Journal of Business Ethics 26 (4): 271-288. doi: 10.1023/A:1006294517573

Yin, R. K. 2011. "Qualitative Research from Start to Finish.“ $2^{\text {nd }}$ ed. New York, NY: Guilford Press.

Zapata-Barrero, R. 2012. "European Migration Governance: From “Anything Goes” to the Need for an Ethical Code." American Behavioral Scientist $56 \quad$ (9): 1183-1203. doi: $10.1177 / 0002764212443820$ 
Managers' Moral Struggle

Types of ethical problems

\begin{tabular}{|c|c|c|c|}
\hline & & \multicolumn{2}{|c|}{ Moral judgment } \\
\hline \multirow{3}{*}{ Moral motivation } & & Indetermined & Determined \\
\cline { 2 - 4 } & High & Genuine dilemma & No-problem problem \\
\cline { 2 - 4 } & Low & Moral laxity & Compliance problem \\
\hline
\end{tabular}

FIGURE 1 Types of ethical problems (Geva 2006). 


\section{An Issue-Contingent Model of Ethical Decision Making in Organizations by Jones (1991)}

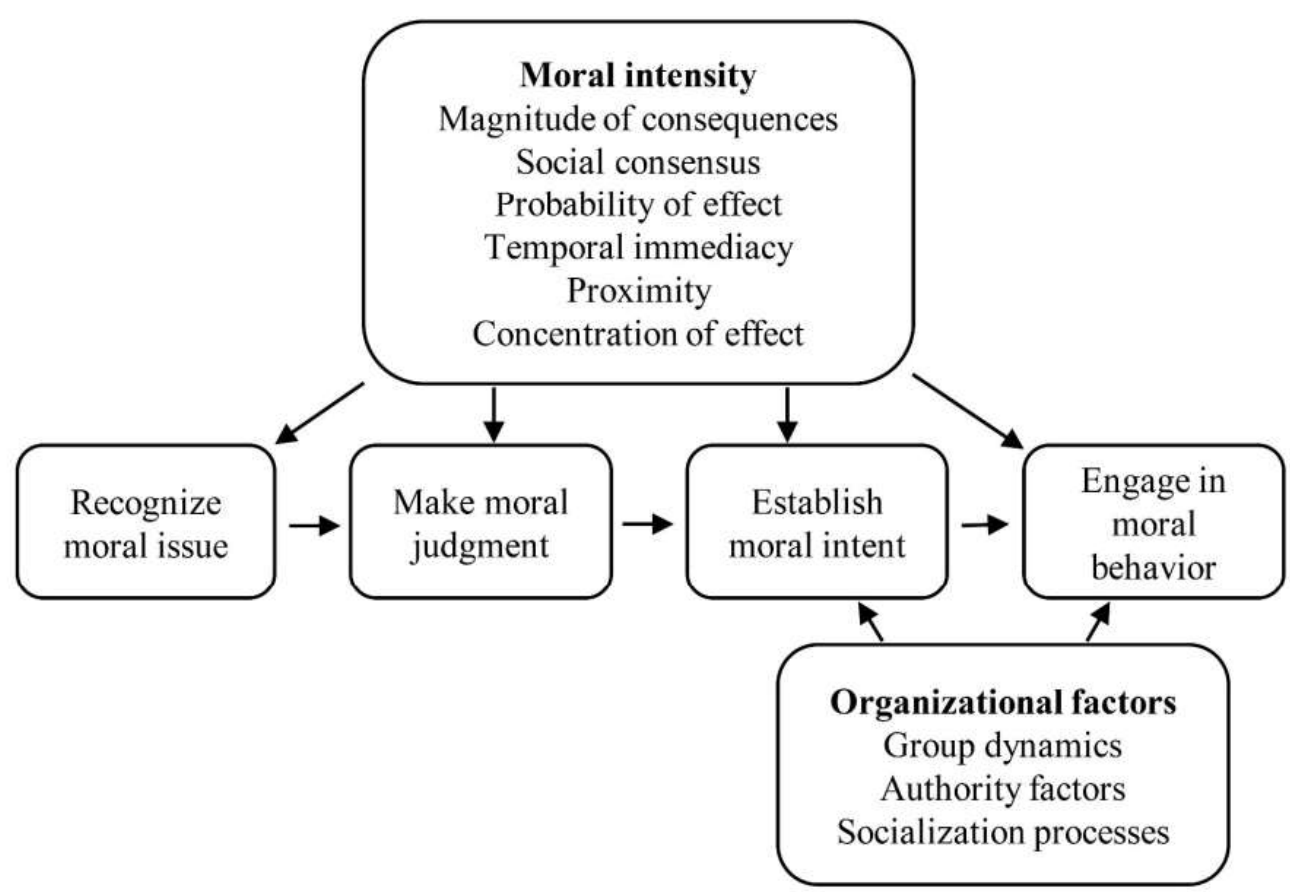

FIGURE 2 Jones's (1991) issue-contingent model of ethical decision-making in organisations. 
Managers' Moral Struggle

TABLE 1 Interviewees' level of education, work experience as a manager of a reception centre, and work experience in the immigration sector.

\begin{tabular}{|c|c|c|c|}
\hline Interviewee & $\begin{array}{c}\text { Education } \\
\text { level }\end{array}$ & $\begin{array}{c}\text { Experience as a reception } \\
\text { centre manager }\end{array}$ & $\begin{array}{l}\text { Experience working } \\
\text { in the immigration } \\
\text { sector }\end{array}$ \\
\hline Mary & Bachelor's & $<1$ year & $1-3$ years \\
\hline James & Bachelor's & $1-3$ years & $1-3$ years \\
\hline Alice & Bachelor's & $1-3$ years & $10-12$ years \\
\hline David & Master's & $<1$ year & $1-3$ years \\
\hline Eva & Bachelor's & $<1$ year & $16-18$ years \\
\hline Paul & Bachelor's & $1-3$ years & $1-3$ years \\
\hline Amanda & Master's & $1-3$ years & $1-3$ years \\
\hline Peter & Doctorate & $4-6$ years & $>20$ years \\
\hline Mike & Bachelor's & $1-3$ years & $1-3$ years \\
\hline Ben & Master's & $7-9$ years & $13-15$ years \\
\hline
\end{tabular}


Managers' Moral Struggle

TABLE 2 Dimensions of moral intensity.

\begin{tabular}{|c|c|}
\hline Dimensions of moral intensity & Examples \\
\hline Magnitude of consequences & $\begin{array}{l}\text { 'And this couple didn't have any immediately life- } \\
\text { threatening illnesses, but (...) which without treatment might } \\
\text { lead to complications. And they had no chance of getting } \\
\text { treatment for these (health problems) without a Finnish } \\
\text { residence permit.' [David] }\end{array}$ \\
\hline Social consensus & $\begin{array}{l}\text { 'I have completely shut off my own opinions from this } \\
\text { decision-making and this work, but surely I can go through a } \\
\text { dialogue with myself about the rightness (...), but on the } \\
\text { other hand I can easily make decisions in those situations and } \\
\text { act consistently because the instructions exist.' [Paul] }\end{array}$ \\
\hline Temporal immediacy & $\begin{array}{l}\text { 'It is so hectic here (...) that you must have good know-how } \\
\text { about the different kinds of options you've got and the law. } \\
\text { (...). Clients' situations can be very painful, and then, what is } \\
\text { our role and what should we do?' [Amanda] }\end{array}$ \\
\hline Proximity & $\begin{array}{l}\text { 'But since you know the person and they're close to you, then } \\
\text { it's more difficult to make a decision that seems to you to be } \\
\text { poor.' [James] }\end{array}$ \\
\hline Concentration of effect & $\begin{array}{l}\text { 'It's very clear that I'm doing much more than is required by } \\
\text { the law (...). Although our responsibility has ended, we aren't } \\
\text { throwing people out onto the streets.' [Amanda] }\end{array}$ \\
\hline
\end{tabular}

